\title{
Project-Based (PjBL) and Guided Inquiry Learning: Students' Response to Rectilinear and Circular Motion Phenomena
}

\author{
${\text { Rismawati*1, } \text { Sarwanto }^{2} \text {, Budiyono Saputro }}^{3}$ \\ ${ }^{1,2}$ Physics Education Master Program, Universitas Sebelas Maret, Surakarta, Indonesia \\ ${ }^{3}$ Science Education, Faculty of Teacher Training and Education, State Institute of Islamic Studies (IAIN) Salatiga, \\ Indonesia
}

*Corresponding address: risma_wati88@student.uns.ac.id

\begin{tabular}{|c|c|}
\hline Article Info & ABSTRACT \\
\hline $\begin{array}{l}\text { Article history: } \\
\text { Received: July 4th, } 2019 \\
\text { Accepted: October } 16 \text { th, } 2019 \\
\text { Published: October } 30^{\text {th }}, 2019\end{array}$ & $\begin{array}{l}\text { The learning method is one of the essential factors that influence the success } \\
\text { of learning. To build good quality learning, choosing the right method is a } \\
\text { crucial step. This study aims to identify differences in student learning } \\
\text { achievement by applying two learning methods, project-based learning } \\
\text { (PjBL) and guided inquiry (GI) in rectilinear motion and circular motion. }\end{array}$ \\
\hline $\begin{array}{l}\text { Keywords: } \\
\text { circular motion; } \\
\text { guided inquiry; } \\
\text { project-based learning; } \\
\text { rectilinear motion; } \\
\text { student achievement }\end{array}$ & $\begin{array}{l}\text { The quasi-experimental method was used in this study. The participants } \\
\text { were selected by cluster random sampling consisting of two classes ( } 36 \\
\text { students and } 35 \text { students) from one of the Vocational Schools in Surakarta. } \\
\text { Data collected through multiple-choice tests and interviews were analyzed in } \\
\text { descriptive and inferential statistics using ANOVA and t-test. The results } \\
\text { show that there is an influence of the learning method on student learning } \\
\text { achievement in which both the PjBL and GI method. Students who learned } \\
\text { rectilinear motion and circular motion using PjBL got higher scores than the } \\
\text { GI method. The implication of this research is as a teacher's reference in } \\
\text { choosing learning methods relevant to the rectilinear motion and circular } \\
\text { motion and its implementation is expected to improve student learning } \\
\text { achievement. }\end{array}$ \\
\hline
\end{tabular}

(C) 2019 Physics Education Department, UIN Raden Intan Lampung, Indonesia

\section{INTRODUCTION}

Physics is one part of natural science that concentrates on abstract characters. Physics material concepts are not only obtained by listening, reading, and demonstrating but must also be done through direct experience so that the concept is more strongly embedded in students' memories (Berge, 2017). The process of physics concept understanding teaches students to think constructively so that students' understanding of physics is intact, both as a process and as a product (Ratnasari, Sukarmin, Suparmi \& Aminah, 2017).

Factors that influence student learning achievement in a learning process are internal and external factors (Cool \& Keith, 1991). One of the external factors that influence learning achievement is the learning method (Aini, Lesmono \& Wahyuni, 2015; Makahinda, 2018) like the 5E (Engage, Explore, Explain, Elaborate, Evaluate) learning method (Cakır, 2017) and 5P (Persuasion, Planning, Performance, Production, And Presentation) learning method (Srikoon, Bunterm, Nethanomsak \& Tang, 2018). One learning method that fits the concept in the 2013 curriculum which emphasizes the scientific approach is Project-Based Learning (PjBL) (Anazifa \& Djukri, 2017). The PjBL method is proven to increase student creativity (Gunawan, Sahidu, Harjono \& Suranti, 2017), student interest, and change students' perceptions in physics learning into a more positive direction (Rosales JR \& Sulaiman, 2016). 
The implementation of the learning method is expected to develop students' attitudes, skills, and knowledge competencies by the mandate of Law Number 20 of 2003 clause 35 that the competencies of a graduate include attitude, knowledge, and skills according to agreed-upon national standards.

Project-based learning is a method that emphasizes the process of contextual learning through more complex activities. This method connects learning through experience to real-world problems (Heckendorn, 2003). Students can become more active individuals in seeking knowledge, collecting data, analyzing, and drawing conclusions when using the PjBL method (Baran \& Maskan, 2010). Projects in the PjBL are tasks assigned to students based on unfamiliar questions or problems according to the topics being discussed and involve students in learning design, decision making, investigative activities, problem-solving, or allowing students to work independently for long periods to produce real products. The implementation of the PjBL method in learning Physics can be done by doing a learning plan in accordance with the syntax of PjBL. The syntax of $\mathrm{PjBL}$ namely: 1) start with the essential question; 2) design a plan for the project; 3) create a schedule; 4) monitor the students and the progress of the projects; 5) assess the outcome; and 6) evaluate the experience (Gerhana, Mardiyana \& Pramudya, 2017).

The inquiry method can also be used in the implementation of the 2013 curriculum with the scientific approach. The main emphasis in inquiry-based learning processes lies in the ability of students to understand, identify carefully and thoroughly, then provide answers or solutions to the problems presented. Also, this learning aims to encourage students to be more courageous and creative in terms of imagination.
One method of inquiry learning that is quite widely applied in schools is the Guided Inquiry (GI) method. Castro \& Morales (2017) suggest that guided inquiry learning promotes classroom practices that help students improve, sharpen, follow their questions, and develop investigations. The implementation of this method also requires the activeness of students who foster students' scientific attitudes. Teaching concepts and relationships between concepts in learning is also intended so that students can find concepts through the necessary instructions from a teacher. Science literacy skills in physics learning can be improved by the implementation of the GI method (Aulia, Poedjiastoeti \& Agustini, 2018) and the ability of science processes and understanding of students' physics concepts (Silaban \& Simanjuntak, 2018). Guided inquiry can be implemented in physics learning by following the syntax of the method. The steps in the process, according to (Trianto, 2012) namely: 1) orientation; 2) formulating problems; 3) formulating hypotheses; 4) collecting data; 5) testing the hypothesis; 6) formulating conclusions. During the learning activity, the teacher takes care of and guides students by giving initial questions and directing them to do a discussion.

Rectilinear motion and circular motion are the initial and supporting subject matter for another subject to be taught in class $X$. The lack of understanding of this material will impact the following material. The characteristics of this material have many terms/vocabularies which is assumed by many as synonyms such as velocity and speed. Another characteristic is that this material tends to be abstract so that it is easy to cause difficulties for students (McLaughlin, 1996). This is the reason for the low student achievement in learning the rectilinear motion and circular motion. The 
choice of the appropriate learning method can be the solution to the problem. The method of PjBL and GI was assessed as a method that approached the appropriate criteria for the rectilinear motion and circular motion subject matter because the material required real evidence through the experimental process with teacher guidance and the making of simple projects. Effective instructions require to understand students' conceptions and challenge students' thinking with direct experience (Watson \& Konicek, 1990).

The concept that will be developed comes from students' interpretation of everyday life experiences about motion. In the $\mathrm{PjBL}$ class, students are asked to learn to design, test, and present the results of simple tools related to the material. Meanwhile in the GI class students with the guidance of the teacher will conduct experiments on rectilinear motion and circular motion.

Research on the use of PjBL has been proven to be successful in improving student achievement (Fini, Awadallah, Parast \& Abu-Lebdeh, 2018), motivation (Chiang \& Lee, 2016), and problemsolving skills (Fajarwati, Susilo \& Indriwati, 2017; Tamba \& Turnip, 2017).

On the other hand, GI has been proven to reduce alternative student conceptions (Barthlow \& Watson, 2014), improve laboratory skills (Nivalainen, Asikainen, \& Hirvonen, 2013) and improve argumentation skills (Acar \& Patton, 2012).
Both methods have been proven to improve various skills. However, a comparison of the effectiveness of the two methods to improve students' achievement on rectilinear motion and circular motion subject matter has not been done. This research is expected to contribute novelty to the selection of effective learning methods to teach rectilinear motion and circular motion subject matter between PjBL and GI. Besides, it is also expected to be a teacher's reference material in the learning process and become a reference for other studies as the development of research that already exists today.

\section{METHODS}

The quasi-experiment method was used in this study. Participants were selected using cluster random sampling consisting of two classes (36 students and 35 students) from one of the Vocational Schools in Surakarta. Data were collected using tests and interviews which were then analyzed with descriptive and inferential statistics using ANOVA and ttest. Interviews are conducted before the learning process takes place. Furthermore, at the end of the learning process, 30 multiple-choice questions were given to test students' understanding of the material for the rectilinear motion and circular motion. The example of the instrument showed in Table 1.

Table 1. The example of the question

\begin{tabular}{|c|c|c|}
\hline Basic competencies & Indicator & Question \\
\hline $\begin{array}{l}\text { Applying the concept of } \\
\text { rectilinear motion and } \\
\text { circular motion with } \\
\text { fixed speed and fixed } \\
\text { acceleration }\end{array}$ & $\begin{array}{l}\text { Applying the concept } \\
\text { of rectilinear motion } \\
\text { and circular motion } \\
\text { with fixed acceleration. }\end{array}$ & $\begin{array}{l}\text { Based on the following examples, decide which } \\
\text { motions belong to rectilinear motion, circular } \\
\text { motion, and accelerated motion are ... } \\
\text { a. Bekel ball that rolls on the sand } \\
\text { b. Volleyball is thrown vertically } \\
\text { c. A bullet fired into the air } \\
\text { d. A ball kicked upside down } \\
\text { e. An apple that fell from a tree }\end{array}$ \\
\hline
\end{tabular}

This study focuses on identifying appropriate learning methods for rectilinear motion and circular motion. The learning activity showed in Table 2 . The 
formulation of the problems in this study was (1) is there any influence of learning methods on student learning achievement, and (2) What is the effectiveness of both the PjBL and GI learning methods.

Table 2. The learning activity

\begin{tabular}{|c|c|c|}
\hline No & Teachers' Activity & Students' Activity \\
\hline 1 & $\begin{array}{l}\text { Asking problems and setting the theme of the } \\
\text { project with students. }\end{array}$ & $\begin{array}{l}\text { Understanding the teacher's } \\
\text { explanation, expressing the opinions/ } \\
\text { ideas of the problems asked by the } \\
\text { teacher, studying the topics to be } \\
\text { selected and investigated as desired. }\end{array}$ \\
\hline 2 & $\begin{array}{l}\text { Giving them the freedom to the students to form } \\
\text { study groups and helping in group work } \\
\text { arrangements }\end{array}$ & $\begin{array}{l}\text { Making small groups, determining } \\
\text { steps for completion, and arranging } \\
\text { work programs. }\end{array}$ \\
\hline 3 & $\begin{array}{l}\text { Facilitating students in finding tools and materials } \\
\text { for practice, supporting the relevant books and } \\
\text { internet access. }\end{array}$ & $\begin{array}{l}\text { Looking for sources needed to practice } \\
\text { and preparing tools and materials } \\
\text { according to the theme. }\end{array}$ \\
\hline 4 & $\begin{array}{l}\text { Accompanying students directly or indirectly during } \\
\text { the investigation process. }\end{array}$ & $\begin{array}{l}\text { Conducting investigations, collecting } \\
\text { data, and analyzing data. }\end{array}$ \\
\hline 5 & $\begin{array}{l}\text { Determining the reporting framework, guiding } \\
\text { students, assess report results, and providing } \\
\text { positive feedback. }\end{array}$ & $\begin{array}{l}\text { Concluding, compiling a written report, } \\
\text { and presenting the results of the report. }\end{array}$ \\
\hline
\end{tabular}

\section{RESULTS AND DISCUSSION}

Learning that has taken place using two learning methods, PjBL and GI, in two different classes is then tested using thirty multiple-choice tests to test the level of understanding of students. ANOVA analysis was conducted to determine whether there was an influence between the learning methods used and student achievement. The results of ANOVA analysis in Table 3 influence the learning method on learning outcomes show a significance level of 0.015 which is smaller than 0.05 , it can be concluded that there is an influence of methods on student learning achievement.
The post-test results were then analyzed to see the effectiveness of the two learning methods through the Levene test and the t-test. In Table 4, the results of the analysis are presented where the second variance of this learning method does not produce a difference ( $\mathrm{sig}>0.05)$. This indicates that the implementation of the two methods has the same effectiveness in learning. The $\mathrm{PjBL}$ and GI methods are effective methods to be applied in the rectilinear motion and circular motion subject matter, so that both can be the choice of the teacher to be used in the learning process.

Table 3. The results of ANOVA influence the learning methods ( $\mathrm{PjBL}$ and GI) on learning outcomes

\begin{tabular}{cccccc}
\hline Source & $\begin{array}{c}\text { Type III Sum } \\
\text { of Squares }\end{array}$ & df & $\begin{array}{c}\text { Mean } \\
\text { Square }\end{array}$ & F & Sig. \\
\hline Corrected method & $1622,365^{\mathrm{a}}$ & 7 & 231,766 & 1,916 & 0,082 \\
Intercept & 321119,758 & 1 & 321119,758 & 2654,784 & 0,000 \\
Method & 750,524 & 1 & 750,524 & 6,205 & 0,015 \\
Error & 7620,412 & 63 & 120,959 & & \\
Total & 381943,690 & 71 & & & \\
Corrected Total & 9242,777 & 70 & & & \\
\hline
\end{tabular}


Table 4. Learning method effectiveness test results

\begin{tabular}{llll}
\hline Effectiveness Test & \multicolumn{2}{l}{$\begin{array}{l}\text { Levene's } \\
\text { Equality of Variances }\end{array}$} & $\begin{array}{l}\text { Test } \\
\text { Means }\end{array}$ \\
\cline { 2 - 4 } & $\mathbf{F}$ & Sig. & Sig. (2-tailed) \\
\hline Equal variances assumed & 3,380 & 0,070 & 0,071 \\
\hline Equal variances not assumed & & & 0,072 \\
\hline
\end{tabular}

These results are in line with previous studies, that the PjBL and GI learning methods have to influence student learning achievement due to the learning steps of both. GI learning methods are proven to increase conceptual understanding and ability to explain students in the concept of density (Almuntasheri, Gillies \& Wright T, 2016) and can improve student literacy science skills (Aulia, Poedjiastoeti \& Agustini, 2018) and critical thinking skills (Nisa, Koestiari, Habibbulloh \& Jatmiko, 2018). The integration of media or learning devices in the implementation of the GI method can increase the effectiveness of the learning process for students such as the use of learning devices with GI methods such as lesson plans, student worksheets, and final tests can produce good quality learning (Asnidar, Khabibah \& Sulaiman, 2018).

Besides being able to improve students' ability to understand the implementation of GI methods, can improve students' scientific work and process skills (Khan, Hussain, Ali, Majoka \& Ramzan, 2011). In the implementation of the GI method students are required to be active in learning. This influences on increasing information storage in long-term memory, so this causes the ability of students' mastery concepts to be improved. With the GI method, students construct concepts and discuss them through the discovery of concepts so students get a lot of meaning knowledge in the long term (Adnan \& Bahri, 2017).

$\mathrm{PjBL}$ is the method that involves the instruction of active student-centered who have characteristics of constructive investigation, collaboration, students' autonomy, goal-setting, communication, and reflection that are associated with the practice of real problems (Kokotsaki, Menzies \& Wiggins, 2016).

The results of previous studies indicate that $\mathrm{PjBL}$ is one of the learning methods that can improve students' outcomes. In research conducted by Baran \& Maskan (2010) shows students who use projectbased learning are more successful than traditional learning. The effectiveness of the PjBL method results in generating students' mathematics learning achievement because students are better able to think actively and creatively (Gerhana, Mardiyana \& Pramudya, 2017).

Students have a good learning environment to solve various problems in daily life. The provision of projects is considered effective in achieving the target cognitive domain. Motivation and problem-solving abilities can be improved using the $\mathrm{PjBL}$ method in learning (Chiang \& Lee, 2016) and PjBL is considered capable of increasing student learning achievement through positive development of attitude (Kızkapan \& Bektaş, 2017; Wafula \& Odhiambo, 2016).

The implementation of brainstorming and project activities in sustainability concepts can improve self-efficacy, communication skills, teamwork, and high-order cognitive skills (Fini, Awadallah, Parast \& Abu-Lebdeh, 2018). It is important to attract students in learning through projects related to material implementation. This activity stimulates students' critical thinking skills through interaction between team members and competition between teams. PjBL learning provides students freedom 
so that they can choose the appropriate topic, resource to be consulted, distribute mutual responsibility among team members (Aldabbus, 2018). Based on the steps taken in the lesson learning how students do the project, the material to be used and the role of participants in designing the final product fosters their intellectual strength in all problemsolving skills, thinking and reflecting on various stages of the project.

The posttest value statistical data of the two classes can be seen in Table 5 . The statistical data from the posttest results of the two classes provide information that the class average with the PjBL method has a higher value $(74,875)$ compared to the GI method class $(69,96)$. This is due to students in the PjBL method class dominated by students with 71-80 interval value criteria while the GI method class is dominated by students with 61-70 interval value criteria (Figure 1). The highest score of the posttest results was obtained by students from the PjBL method class with a score of 96.6 and the lowest score (43.3) obtained by the GI class students. Based on these data, although both have the same effectiveness, the level of understanding of students is higher when the learning process uses the PjBL method. This shows that physics learning using the PjBL method is better than using the GI method; students more easily understand the material using the $\mathrm{PjBL}$ method.

Table 5. Descriptions of Cognitive Learning Achievement Statistics for the GI and PJBL Methods

\begin{tabular}{ccc}
\hline Statistic & $\begin{array}{c}\text { GI Learning } \\
\text { Achievement }\end{array}$ & $\begin{array}{c}\text { PjBL } \\
\text { Learning } \\
\text { Achievement }\end{array}$ \\
\hline Mean & 69,96 & 74,875 \\
\hline Median & 70 & 73,3 \\
\hline Stdev & 12,47 & 10,03 \\
\hline Var & 155,60 & 100,67 \\
\hline Max & 93,3 & 96,6 \\
\hline Min & 43,3 & 50 \\
\hline
\end{tabular}

The standard deviation of the learning achievement values in the class using the PjBL method (10.03) is smaller than the standard deviation of the class using the GI method (12.47). This shows that the difference in test scores from one another in the class using the PjBL method is smaller (the data is more collected) than the value of the learning achievement test in the class using the GI method. Cognitive learning achievement histogram graphs between classes applying the $\mathrm{PjBL}$ method and classes using the GI method are shown in Figure 1.

The successful use of the PjBL method in vocational high schools (SMK) is also inseparable from the process of planting new knowledge concepts in this method. Students are directed to the concepts or initial knowledge that supports, recalls the procedures carried out and the facts of the experiment results which are then analyzed to conclude in the form of a project (Ergül \& Kargin, 2014). Based on Thomas (2000) methodologically students are directed to construct concepts or theories that are new to them, so that they have a record of events, observed objects and obtain facts, thus they gain an understanding that can be interpreted through tables, diagrams, or graphs and generalize so that they are able to solve problems that submitted.

Learning with $\mathrm{PjBL}$ refers to the driving question which is very much related to the material of rectilinear motion and circular motion (Thomas, 2000). Driving questions at the beginning of learning have a broad and not specific scope, so students need to make inventions and innovations by adding questions to create specific projects. During learning activities, the teacher acts as facilitator and accompanies students. Teachers and other groups can provide advice and feedback to improve the results of the projects being carried out. This provides opportunities for students 
to rethink and improve their projects (Kean \& Kwe, 2014). Students work together in groups to schedule, design and complete projects given (Mioduser \& Betzer, 2008).

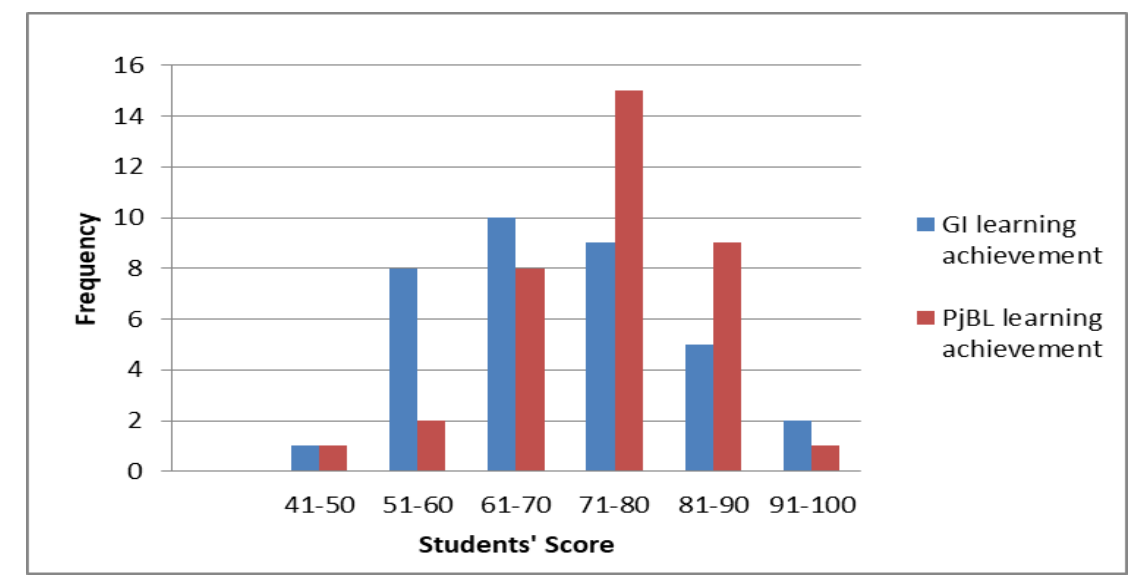

Figure 1. Learning achievement histogram using the PjBL and GI methods

PjBL learning involves many experiments in making projects so that it helps students to appreciate the meaning of the experiments carried out and key questions, revealing good reflective thinking among their peers. The results of this study are in accordance with the research Erguil \& Kargin (2014) which shows that learning using the $\mathrm{PjBL}$ method has a good influence on learning outcomes. Projects produced in PjBL are completed by students through group work so that they can motivate them to learn to each student to work together and interact with other group members.

This showed that project-based learning can encourage students to be more active in the learning process and give them freedom of creation so that they are expected to be able to apply it in reallife conditions (Esteban \& Arahal, 2015). Project is a complicated task based on challenging questions or problems, involving students in learning design, problem-solving, decision making, or investigative activities; allowing students to work relatively independently for long periods, and produce real or presentation products (Fernandes, 2016). This learning is built on learning activities that involve student interest and motivation.

\section{CONCLUSION}

The selection of learning methods is one important step in creating quality learning. Based on the results of the study it is proven that the implementation of learning methods influences student learning achievement. Between the two learning methods studied, PjBL and GI, both of them did not give a difference in effectiveness in their use in the learning process so that the two methods were considered equally effective when applied in rectilinear motion and circular motion subject matter. However, the posttest value of students in the class with the PjBL method was higher than the class with the GI method. This indicates that the PjBL method is more accepted by students in understanding the material of rectilinear motion and circular motion.

\section{AUTHOR CONTRIBUTIONS}

RW conceptualizes and designs research. ST collects and analyzes data. BS describes the results and discussion.

\section{REFERENCES}

Acar, O., \& Patton, B. R. (2012). Argumentation and Formal Reasoning Skills in an 
Argumentation- Based Guided Inquiry Course. Procedia - Social and Behavioral Sciences, 46, 47564760.

https://doi.org/10.1016/j.sbspro.2012 .06 .331

Adnan, \& Bahri, A. (2017). Beyond Effective Teaching: Enhancing Students' Metacognitive Skill Through Guided Inquiry. IOP Conf.Series: Journal of Physics, (954). https://doi.org/10.1088/17426596/954/1/012022

Aini, Q., Lesmono, A. D., \& Wahyuni, S. (2015). Pembelajaran Fisika Menggunakan Model Project Based Learning dengan Memanfaatkan Bahan Bekas. Jurnal Pembelajaran Fisika, 7(1), 1-7.

Aldabbus, S. (2018). Project-Based Learning: Implementastion \& Challenges. Internatioanl Journal of Educationm Learning and Development, 6(3), 71-79.

Almuntasheri, S., Gillies, R. M., \& Wright T. (2016). The Effectiveness of a Guided Inquiry-Based, Teachers' Professional Development Programme on Saudi Students' Understanding of Density. Science Education International, 27(1), 1639.

Anazifa, R. D., \& Djukri. (2017). ProjectBased Learning and Problem-Based Learning: Are They Effective to Improve Student's Thinking Skills? Jurnal Pendidikan IPA Indonesia, $6(2)$, 346-355. https://doi.org/10.15294/jpii.v6i2.11 100

Asnidar, Khabibah, S., \& Sulaiman, R. (2018). The Effectiveness of Guided Inquiry Learning for Comparison Topics. Journal of Physics: Conference Series, 947(1). https://doi.org/10.1088/17426596/947/1/012033

Aulia, E. V, Poedjiastoeti, S., \& Agustini, R. (2018). The Effectiveness of
Guided Inquiry-Based Student Worksheets on Students' Generic Science Skills. Journal of Physics: Conference Series, (947). https://doi.org/10.1088/17426596/1088/1/012106

Baran, M., \& Maskan, A. (2010). The Effect of Project-Based Learning on Pre-Service Physics Teachers' Electrostatic Achievements. Cypriot Journal of Educational Sciences, 5, 243-257.

Barthlow, M. J., \& Watson, S. B. (2014). The Effectiveness of ProcessOriented Guided Inquiry Learning to Reduce Alternative Conceptions in Secondary Chemistry. School Science and Mathematics, 114(5), 246-255.

Berge, M. (2017). The Role of Humor in Learning Physics: a Study of Undergraduate Students. Research in Science Education, 47(2), 427-450. https://doi.org/10.1007/s11165-0159508-4

Cakır, N. K. (2017). Effect of 5E Learning Model on Academic Achievement, Attitude and Science Process Skills: Meta-Analysis Study. Journal of Education and Training Studies, $\quad 5(11), \quad 157$. https://doi.org/10.11114/jets.v5i11.2 649

Castro, J. A. F., \& Morales, M. P. E. (2017). "Yin" in a Guided Inquiry Biology Vlassroom - Exploring Student Challenges and Difficulties. Journal of Turkish Science Education, 14(4), 48-65. https://doi.org/10.12973/tused.10212 a

Chiang, C. L., \& Lee, H. (2016). The Effect of Project-Based Learning on Learning Motivation and ProblemSolving Ability of Vocational High School Students. International Journal of Information and Education Technology, 6(9), 709712. 
https://doi.org/10.7763/IJIET.2016.V 6.779

Cool, V. A., \& Keith, T. Z. (1991). Testing a Model of School Learning: Direct and Indirect Effects on Academic Achievement. Contemporary Educational Psychology, 16(1), 28-44. https://doi.org/10.1016/0361476X(91)90004-5

Ergül, N. R., \& Kargın, E. K. (2014). The Effect of Project Based Learning on Students' Science Success. Procedia - Social and Behavioral Sciences, 136, 537-541. https://doi.org/10.1016/j.sbspro.2014 .05 .371

Esteban, S., \& Arahal, M. R. (2015). Project Based Learning Methodologies Applied to Large Groups of Students: Airplane Design in a Concurrent Engineering Context. IFAC-Papers Online, 48(29), 194-199. https://doi.org/10.1016/j.ifacol.2015. 11.236

Fajarwati, S. K., Susilo, H., \& Indriwati, S. E. (2017). Pengaruh Project Based Learning Berbantuan Multimedia terhadap Keteampilan Memecahkan Masalah dan Hasil Belajar Pskomotor Siswa Kelas XI SMA. Jurnal Pendidikan: Teori, Penelitian Dan Pengembangan, 2(3), 315-321.

Fernandes, M. A. (2016). Project Based Learning Applied to An Embedded Systems Course. International Journal of Electrical Engineering Education, 54(3), 223-235. https://doi.org/10.1177/00207209166 75830

Fini, E. H., Awadallah, F., Parast, M. M., \& Abu-Lebdeh, T. (2018). The Impact of Project-Based Learning on Improving Student Learning Outcomes of Sustainability Concepts in Transportation Engineering Courses. European Journal of Engineering Education, 43(3), 473-
488.

https://doi.org/10.1080/03043797.20 17.1393045

Gerhana, M. T. C., Mardiyana, M., \& Pramudya, I. (2017). The Effectiveness of Project Based Learning in Trigonometry. Journal of Physics: Conference Series, 895(1). https://doi.org/10.1088/17426596/895/1/012027

Gunawan, Sahidu, H., Harjono, A., \& Suranti, N. M. Y. (2017). The Effect of Project Based Learning with Virtual Media Assistance on Student's Creativity in Physics. Cakrawala Pendidikan, 2, 167-179.

Heckendorn, R. B. (2003). Building a Beowulf: Leveraging Research and Department Needs for Student Enrichment via Project Based Learning. Computer Science Education, 12(4), 255-273. https://doi.org/10.1076/csed.12.4.255 .8620

Kean, A. C., \& Kwe, N. M. (2014). Meaningful Learning in the Teaching of Culture: The Project Based Learning Approach. Journal of Education and Training Studies, 2(2), 189-197. https://doi.org/10.11114/jets.v2i2.27 0

Khan, M. S., Hussain, S., Ali, R., Majoka, M. I., \& Ramzan, M. (2011). Effect of Inquiry Method on Achievement of Students in Chemistry At Secondary Level. International Journal of Academic Research, 3(1), 955-960.

Kizkapan, O., \& Bektaş, O. (2017). The Effect of Project Based Learning on Seventh Grade Students' Academic Achievement. International Journal of Instruction, 10(1), 37-54. https://doi.org/10.12973/iji.2017.101 $3 \mathrm{a}$

Kokotsaki, D., Menzies, V., \& Wiggins, A. (2016). Project-Based Learning: A Review of the Literature. 
Improving Schools, 19(3), 267-277. https://doi.org/10.1177/13654802166 59733

Makahinda, T. (2018). The Effect of Learning Based on Technology Model and Assessment Technique toward Thermodynamic Learning Achievement. IOP Conference Series: Materials Science and Engineering, 306(1). https://doi.org/10.1088/1757899X/306/1/012125

McLaughlin, S. (1996). Rounding Up Students' Conceptios on Circular Motion. Iowa Science Teachers Journal, 33(2), 7-15.

Mioduser, D., \& Betzer, N. (2008). The contribution of project-basedlearning to high-achievers' acquisition of technological knowledge and skills. International Journal of Technology and Design Education, 18(1), 59-77. https://doi.org/10.1007/s10798-0069010-4

Nisa, E. K., Koestiari, T., Habibbulloh, M., \& Jatmiko, B. (2018). Effectiveness of guided inquiry learning model to improve students' critical thinking skills at senior high school. Journal of Physics: Conference Series, 997(1). https://doi.org/10.1088/17426596/997/1/012049

Nivalainen, V., Asikainen, M. A., \& Hirvonen, P. E. (2013). Open Guided Inquiry Laboratory in Physics Teacher. Journal of Science Teacher Education, 24(3), 449-474. https://doi.org/10.1007/s10972-0129316-x

Ratnasari, D., Sukarmin, S., Suparmi, S., \& Aminah, N. S. (2017). Students' Conception on Heat and Temperature toward Science Process Skill. Journal of Physics: Conference Series, 895(1). https://doi.org/10.1088/17426596/895/1/012044
Rosales JR, J. J., \& Sulaiman, F. (2016). Students' Personal Interest Towards Project - Based Learning. PEOPLE: International Journal of Social Sciences, 2(1), 214-227. https://doi.org/10.20319/pijss.2016.s 21.214227

Silaban, A., \& Simanjuntak, M. P. (2018). Pengaruh Model Pembelajaran Inkuiri Terbimbing terhadap Ketrampilan Proses Sains dan Pemahaman Konsep Fisika. Jurnal Pendidikan FIsika, 7(1), 20-24.

Srikoon, S., Bunterm, T., Nethanomsak, T., \& Tang, K. N. (2018). Effect of 5P Model on Academic Achievement, Creative Thinking, and Research Characteristics. Kasetsart Journal of Social Sciences, 39(3), 488-495. https://doi.org/10.1016/j.kjss.2018.0 6.011

Tamba, P., \& Turnip, B. M. (2017). The Effect of Project Based Learning Model for Students ' Creative Thinking Skills and Problem Solving. Journal of Research \& Method in Education, 7(5), 67-70. https://doi.org/10.9790/73880705026770

Thomas, J. W. (2000). A Review of Research on Project-Based Learning. San Rafael: The Autodesk Foundation

Trianto. (2012). Model Pembelajaran Terpadu. Jakarta: Bumi Aksara.

Wafula, W. N., \& Ongunya Odhiambo. (2016). Project Based Learning on Students' Performance in the Concept of Classification of Organisms among Secondary Schools in Kenya. Journal of Education and Practice, 7(16), 2531.

Watson, B., \& Konicek, R. (1990). Teaching for Conceptual Change: Confronting Children's Experience. Source: The Phi Delta Kappan, 71(9), 680-685. 